\title{
PENGUKURAN KUALITAS LAYANAN PADA BISNIS JASA
}

\author{
Yasrizal \\ Universitas Teuku Umar, Meulaboh \\ Email :
}

\begin{abstract}
ABSTRAK
The global economy today has encouraged the growth of rapidly growing service business. Many jobs can be developed, such as healthcare, hospitality, service station, fast food, laundry, telecommunications, and others. The presence of a variety of business services has sparked fierce competition among service businesses. To anticipate this service managers should seek to provide or pay attention to the quality of services offered, so that consumers are satisfied. To maintain the quality of service always remains good, the service managers need to pay attention to dimensions-dimensional measurement of service quality. By measuring the quality of services, the manager informed about the extent of services provided has to meet consumer expectations.
\end{abstract}

Keyword:service quality, performance score, services provided, Hopes services

\section{PENDAHULUAN}

Seseorang menjalankan kegiatan bisnis, didasarkan atas dorongan untuk memenuhi kebutuhan konsumen, serta untuk memperoleh uang/keuntungan. Perekonomin global dewasa ini telah mendorong pertumbuhan sektor binis jasa. Pertumbuhan ini sejalan pula dengan pertumbuhan kesempatan kerja. Di Indonesia perkembangan sektor jasa berlangsung sangat pesat sejak tahun 1995 sampai sekarang. Hal ini jelas telihat banyak bisnis sektor jasa yang tumbuh dan berkembang dalam manyarakat.

Banyak lapangan usaha dibidang jasa yang dapat dikembangkan. Lapangan usaha tersebut, misalnya perhotelan, perbankkan, bengkel, laundry, telekomunikasi, kesehatan dan lain sebagainya.Munculnya berbagai bisnis jasa detengah-tengah masyarakat telah mendorong persaingan yang semakin tajam pada bisnis jasa tersebut. 
Untuk memenangkan persaingan, pengelola binsis jasa harus berupaya menerapkan strtegi pemasaran yan tepat dalam mengelola bisnis. Pengelola harus berupaya memberikan kepuasan kepada konsumen melebihi para saingan, serta keunggulan-keunggulan bersaing dalam bauran pemasaran jasa ( servicemarketing mix). Bauran pemasaran adalah sekelompok kiat yang dijalankan oleh pempinan dalam menghadapi pasar sasaran. Sekelompok kiat tersebut terdiri dari 7P (product/service (produk/jasa), price (harga), promotion (promosi), palce (tempat), participation/ people (orang), process (proses), dan Physical evidence. (Murdik, dkk 1998). Sementara bauran pemasarn untuk barang hanya iterdiri 4P yaitu, product, price, promotion, dan place. ( Alma, 2008). Dalam memasarkan pruduk jasa, pengelola harus benar-benar dapat mengkombinasikan sekelompok kiat di atas dengan tepat dalam upaya memuaskan konsumen. Kepuasan konsumen merupakan kunci kesuksesan dalam menjalankan kegiatan bisnis.

Kepuasan berhubungan dengan kualitas jasa yang ditawarkan, seperti kehadalan, kecepatan, kepampuan, kemudahan, keramah-tamahan para karyawan dalam melayani konsumen, dan lain-lain. Puas tidak seorang konsumen tergantung pada baik tidaknya kulitas jasa yang disediakan tersebut. Tanpa memperhatikan demensi-demensi atau variable-variabel dalam kualitas jasa, maka perusahaan tidak dapat memberikan pelayanan yang memuaskan pada konsumen. John Sviokla menjelaskan salah satu factor yang menentukan keberhasilan dan kualitas perusahaan adalah kemampuan perusaan memberikan pelayanan kepada pelanggan (Lupiyoadi, dkk 2009). Keberhasilan perusahaan.dalam memberikan pelayanan dapat menetukan tingkat kepuasan kepada pelanggan. Dengan pengukuran tersebut dapat diketahui sejauhmana konsumen telah puas terhadap jasa yang ditawarkan dan dijanjikan. Namun persoalannya adalah ada sejumlah variabel atau demensi yang perlu dipahami dalam mengukur kualitas jasa. Hal inilah yang ingin dibahas lewat kajian sederhana ini.

\section{KONSEP JASA}

Istilah jasa tidak asing lagi bagi masyarakat. Hampir setiap hari masyarakat menggunakan berbagai jasa yang ditawarkan oleh penyedia jasa. Akan tetapi apa arti jasa itu, banyak yang belum memahami. Pada dasarnya jasa merupakan suaut produk yang mepunyai karakteristik yang khas, yang membedakan dengan produk barang. Jasa sering dipandang sebagai sesuatu yang unik, karena memiliki karakteristik yang unik pula. Kata jasa itu sendiri mempunyai banyak arti, seperti bermakna pelayanan pribadi, jasa sebagai suatu produk. 
Banyak para ahli yang telah memberikan makna jasa. Kotler (2000) memberikan arti Jasa adalah setiap kegiatan atau mamfaat yang ditawarkan oleh suatu pihak kepihak lain yang pada dasarnya tidak berujud, serta tidak menghasilkan kepemilikan sesuatu . Proses produksinya terkait dan mungkin juga tidak dikaitkan dengan produk. Lebih lanjut Valarie A. Zethaml dan Mary J Bitner (Lupiyoadi, dkk 2009) memberikan batasan tentan jasa adalah semua aktivitas ekonomi yang hasilnya bukan berbentuk produk fisik atau kontruksi, yang umumnya dihasilkan dan dikonsumsi secara bersamaan serta memberikan nilai tambah, misalnya kenyamanan, hiburan, kesenangan, atau kesehatan.

Karena itu pemasaran jasa sangat unik, sebab jasa punya karektik yang berbeda dengan barang. Jasa mempunyai karakteristik yang tidak berujud, tidak dapat dipisahkan, berubah-ubah dan tidak dapat disimpan. Ciri lain dari jasa adalah produksi dan konsumsi bersamaan waktu dan kurang memiliki standar. Contohnya adalah, bengkel, salon kecantikan, hotel, rumah sakit, tukang pangkas, Telkomsel, pendidikan, dan lain-lain.

Jasa bersifat tidak berujud, artinya tidak dapat dilihat, diraba, dirasa sebelum dibeli. Seseorang tidak dapat menilai hasil dari jasa sebelum ia menikmati sendiri. Karena itu, untuk mengurangi hal-hal yang tidak diinginkan oleh pelanggan, maka pelanggan akan memerhatikan bukti-bukti atau tanda- tanda kualitas jasa tersebut.

Ciri lain jasa adalah waktu produksi dan konsumsi bersamaan, artinya jasa bukan diproduksi lebih dahulu baru kemudian dikonsumsi. Misalnya, aktivitas mahasiiswa/siswa dalam pendidikan, di mana guru dan murid terlibat dalam proses produksi di satu pihak dan konsumsi di lain pihak. Karena itu efektivitas individu yang menyampaikan jasa merupakan unsur penting.

Di sisi lain jasa kurang memiliki standard dan tidak tahan lama. Jasa tidak dapat diukur standarnya apa, setiap saat berubah-ubah dan sangat tergantung di mana, kapan, kepada siapa jasa dihasilkan. Pengguna jasa sangat sensitif terhadap variasi jasa yang ditawarkan. Jasa juga tidak tahan lama dan tidak bisa disimpan. Misalnya, kursi mobil yang kosong, kamar hotel yang tidak ditempati. Hal itu tentu akan mubazir begitu saja jika tidak disimpan.

Oleh karena jasa memiliki karakteristik seperti disebutkan di atas, maka pemasaran jasa harus mempunyai kiat-kiat khusus yang berbeda dengan pemasaran produk barang. Pemasaran jasa tidak hanya cukup dengan melakukan promosi saja, melainkan harus melalui strategi pemasaran jasa yang 
terdiri dari kombinasi produk/jasa, harga, promosi, tempat, orang, proses, dan fasilitas fisik. Terutama pada sektor jasa murni yang sangat sulit dilakukan. Hal ini dikarenakan konsistensi kinerja jasa sangat sukar dijaga. Namun, pada jasa yang tidak murni, seperti sewa mobil, reparasi, kaset video, pemasarannya tidak terlalu sukar, malah hamper sama dengan pemasaran barang. Sebab jenis jasa ini memerlukan barang-barang fisik yang didukung oleh pelayanan.

\section{DIMENSI PENGUKURAN KUALITAS JASA}

Tujuan utama didirikan suatu bisnis adalah untuk memperoleh keuntungan. Untuk mencapai maksud tersebut, pengelola bisnis jasa harus menjalankan berbagai strategi dan selalu berupaya untuk meningkatkan kualitas jasa yang diberikan guna memuaskan konsumen. Memahami kualitas pada jasa tentu sangat silit, karena jasa sesuatu yang tidak tampak jelas. Berbeda halnya dengan barang, yang dapat dengan mudah dilihat apakah barang tersebut berkualitas atau tidak.

Kualitas jasa pada hakikatnya adalah mutu yang dihasilkan penyedia jasa, dengan menggunakan berbagai fasilitas dan daya dukung lainnya yang dimiliki. Kualitas jasa akan ditentukan oleh para pemakai jasa. Apakah jasa yang disediakan dapat memenuhi harapan pelanggan atau tidak.

Untuk lebih jelas tentang makna kualitas jasa, dapat dilihat pada pengertian berikut: kualitas jasa adalah upaya pemenuhan kebutuhan dan keinginan pelanggan serta ketepatan penyampaiannya untuk mengimbangi harapan pelanggan (Tjiptono, 2004). Lebih lanjut Wykof dalam Tjiptono (2004) menyebutkan bahwa kualitas jasa adalah tingkat keunggulan yang diharapkan dan pengendalian atas tingkat keunggulan tersebut untuk memenuhi keinginan pelanggan. Dalam hal ini ada dua factor yang diharapkan, sehinngga jasa berhubungannya erat dengan kepuasan pelanggan.

Kualitas jasa dimulai dan berakhir pada pelanggan. Ini berarti bahwa citra kualitas yang baik bukanlah berdasarkan sudut pandang dan persepsi pihak penyedia jasa, melainkan berdasarkan pada kebutuhan dan keninginan pelanggan. Pelanggan yang mengkonsumsi dan menikmati jasa perusahaan, sehingga mereka yang menentukan baik buruknya kualitas jasa yang dikonsumsikan. Persepsi pelanggan terhadap kualitas jasa merupakan penilaian menyeluruh atas keunggulan kualitas jasa.

Untuk mengukur kualitas jasa perlu memerhatikan dimensi (variabel-variabel) yang terkait di dalamnya. Garvin dalam (Tjiptono 1998), mengembangkan delapan dimensi kualitas jasa yaitu kinerja (ferfomance), keistimewaan tambahan (features), keandalan (reability), kesesuaian dengan spesifikasi 
(conformance to specification), daya tahan, (durability), Kecepatan, kompetensi, (servisebility), estitika, dan kualitas yang dpersepsikan (perceived quality). Sementara Perasuraman, dkk (Lupiyoadi, 2009) mengidentifikasi lima dimensi pokok kualitas jasa. Lima dimensi ini sering digunakan dalam berbagai penelitian, yaitu sebagai berikut:

1. Berwujud (tangible), yaitu kemampuan suatu perusahaan dalam menunjukkan eksisistensinya kepada pihak eksternal. Penampila dan kemampuan sarana dan prasarana fisik perusahaan yang dapat diandalkan keadaan lingkungan sekitarnya merupakan bukti nyata dari pelayanan yang diberikan oleh pemberi jasa. Hal ini meliputi fasilitas fisik (contoh: gedung, gudang, dll), perlengkapan dan peralatan yang digunakan (teknologi), serta penampilan pegawainya.

2. Keandalan (reliability), yaitu kemampuan perusahaan untuk memberikan pelayanan sesuai dengan yang dijanjikan secara akurat dan terpercaya. Kinerja harus sesuai dengan harapan pelanggan yang berarti ketepatan waktu, pelayanan yang sama untuk semua pelanggan tanpa kesalahan, sikap yang simpatik, dan akurasi kerja yang tinggi.

3. Ketanggapan (responsiveness), yaitu suatu kebijakan untuk membantu dan memberikan pelayanan yang cepat (responsive) dan tepat kepada pelanggan, dengan penyampaian informasi yang jelas.

4. Jaminan dan kepastian (assurance), pengetahuan, kesopansantunan, dan kemampuan para pegawai perusahaan untuk menumbuhkan rasa percaya pada pelanggan kepada perusahaan. Hal ini meliputi beberapa komponen antara lain komunikasi, kredibelitas, keamanan, kompetensi, dan sopan santun.

5. Empati (empathy), yaitu memberikan perhatian yang tulus dan bersifat individual atau pribadi yang diberikan kepada para pelanggan dengan berupaya memahami keinginan konsumen. Di mana suatu perusahaan diharapkan memiliki pengertian dan pengetahuan tentang pelanggan, memahami kebutuhan pelanggan secara spesifik, serta memiliki waktu pengoperasian yang nyaman bagi pelanggan.

Semua dimensi di atas harus mendapat perhatian serius dari pengelola agar pelanggan dapat menikmati jasa dengan puas. Karena dewasa ini kepuasan pelanggan telah dijadikan kunci dalam meraih keberhasilan perusahaan.

Untuk menghasilkan suatu pelayanan yang berkualitas, perusahaan dapat mengukur pelayanan yang telah diberikan kepada pelanggan melalui skala pengukuran tertentu. Mengukur kualitas jasa 
berarti mengevaluasi/ membandingkan kinerja dengan seperangkat standar yang telah ditetpakan terlebih dahulu. Kualitas jasa dapat diukur dengan memperhatikan lima dimensi kualitas jasa seperti yang telah diuraikan di atas. Dalam hal ini SERVQUAL (service quality) memiliki aplikasi skala pengukuran yang disebut dengan multiple-item scale. Skala dengan validitas dan reliabilitas yang baik tersebut digunakan perusahaan untuk dapat mengerti lebih baik, tentang harapan dan persepsi pelanggan akan pelayanan yang diinginkan, yang dapat menghasilkan peningkatan pelayanan.

Instrument dalam skala tersebut didesain untuk bermacam bentuk pelayanan. Instrument tersebut merupakan suatu format dalam menentukan harapan dan persepsi pelanggan, serta dapat digunakan untuk menentukan kualitas jasa suatu perusahaan atas dasar lima dimensi kaulitas jasa. Caranya dengan merata-ratakan perbedaan nilai yang dihasilkan dari masing-masing bagian yang membentuk kelima dimensi.

Beberapa alternative lain yang dapat digunanakan guna menentukan besarnya kualitas jasa yaitu sebagai berikut:

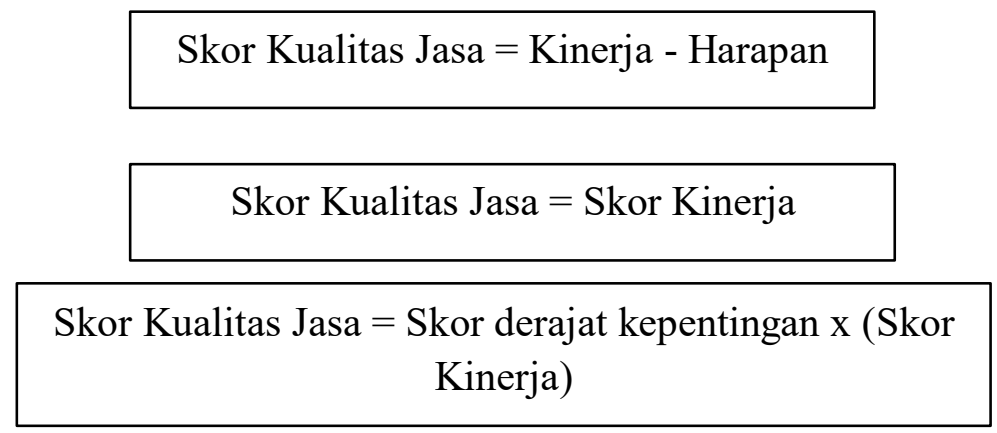

Untuk mengukur kualitas jasa tentu harus disiapkan sejumlah pertanyaan yang akan dinilai oleh responden/pelanggan. Pertanyaan tersebut dirancang sesuai dengan indikator pada masing-masing demensi. Pertanyaan dapat dibuat dalam bentuk skala Likert dengan rentang skor 1 sampai 5. Sisi paling negative dinyatakan sangat tidak setuju/ sangat tidak baik, dan sisi paling positif dengan sangat setuju/sangat baik. Pelanggan akan menjawab setiap butir pertanyaan berdasarkan seberapa baik pelayanan yang diterimanya.

Dimensi-dimensi kualitas jasa di atas harus diaduk sedemikian rupa agar tidak menimbulkan kesenjangan antara perusahaan dan pelanggan yang disebabkan perbedaan persepsi mereka tentang keberadaan pelayanan. Bila terjadi kesenjangan, maka perusahaan harus berupaya untuk 
mengantisipasi kesenjangan tersebut dengan jalan meningkatkan kualitas pelayan kepada konsumen. Lupiyoadi (2009) mengemukakan lima kesenjangan (gap) yaitu sebagai berikut:

1. Kesenjangan persepsi manajemen. Yaitu adanya perbedaan antara penilaian pelayanan menurut pengguna jasa dan persepsi manajemen mengenai harapan pengguna jasa.

2. Kesenjangan spesifikasi kualitas. Yaitu kesenjangan antara persepsi manajemen mengenai harapan pengguna jasa dan spesifikasi kualitas jasa.

3. Kesenjangan penyampaian jasa. Yaitu kesenjangan antara spesifikasi kualitas jasa dan penyampaian jasa.

4. Kesenjangan komunikasi pemasaran. Yaitu kesenjangan antara penyampaian jasa dan komunikasi eksternal.

5. Kesenjangan dalam pelayanan yang dirasakan. Yaitu perbedaan persepsi antara jasa yang dirasakan dan yang diharapkan oleh pelanggan.

Pengukuran kualitas jasa tentu sangat penting. Dengan pengukuran kualitas jasa, .pengelolan akan memproleh masukan informasi tentang kualias jasa yang disediakan. Dengan demikian dapat menentukan strategi yang tepat dalam upaya meningkatkan mutu jasa yang ditawarkan. Kualitas jaya yang baik tentu akan menghasilkan loyalitas konsumen yang baik pula. Artinya bila kualitas jasa yang dinikmati konsumen baik, maka konsumen akan mengulangi pembelian jasa tersebut di masa akan datang.

\section{PENUTUP}

Untuk mengukur kualitas jasa yang ditawarkan kepada anak didik ada beberapa dimensi yang harus diperhatikan. Dimensi tersebut adalah tangible, realibility, responsiveness, assurance, dan emphaty. Dengan memerhatikan kualitas jasa, berarti memerhatikan masalah kepuasan konsumen. Kualitas jasa akan tercermin pada sarana dan prasarana serta kemampuan staf yang dimilki tersebut. Semua dimensi ini harus dijabarkan dengan baik, sehingga dapat mengevaluasi kinerja suatu perusahaan dan harap konsumen, sehingga dapat diketahui berapa besar tingkat kepuasan dan gap dari kualitas jasa yang ditawarkan. 


\section{DAFTAR PUSTAKA}

Alma, Bukhari. (2008). Pengantar Bisnis. Bandung: Penerbit Alfabeta.

Goncolves, K. P. (1998). Services Marketing, Printed in the United State of American.

Kotler, Fhilip. (2000). Marketing management, analysis, planning, implementation and control, New Jersey: Prentice Hall International.

Murdik, dkk. (1998). Operational Service. Penerbit: Alim, Bacon, Boston.

Lupiyoadi, Rambat, dkk. (2009). Manajemn Pemasaran Jasa. Jakarta: Salemba Empat.

Tjiptono, F. (2004). Manajemen pemasaran jasa. Jakarta: Penerbit: Rineka Cipta.

(1998). Manajemen Pemasaran Jasa. Yogyakarta, Penerbit: Andi Offset. 